NOTICE: this is the author's version of a work that was accepted for publication in the journal Construction and Building Materials.

Changes resulting from the publishing process, such as peer review, editing, corrections, structural formatting, and other quality control mechanisms may not be reflected in this document. Changes may have been made to this work since it was submitted for publication. A definitive version was subsequently published in the journal Construction and Building Materials, Vol.66 (2014). DOI: http://doi.org/10.1016/j.conbuildmat.2014.05.080 


\section{Elsevier Editorial System(tm) for Materials and Design Manuscript Draft}

Manuscript Number: JMAD-D-14-00639R2

Title: The effects of ground granulated blast-furnace slag blending with fly ash and activator content on the workability and strength properties of geopolymer concrete cured at ambient temperature

Article Type: Original Article

Keywords: Ambient curing; geopolymer; ground granulated blast-furnace slag; fly ash; tensile strength; workability

Corresponding Author: Mr. Partha Sarathi Deb,

Corresponding Author's Institution: Curtin University, Australia

First Author: Partha Sarathi Deb

Order of Authors: Partha Sarathi Deb; Pradip Nath; Prabir K Sarker, PhD

Abstract: Inclusion of ground granulated blast furnace slag (GGBFS) with class F fly-ash can have a significant effect on the setting and strength development of geopolymer binders when cured in ambient temperature. This paper evaluates the effect of different proportions of GGBFS and activator content on the workability and strength properties of fly ash based geopolymer concrete. In this study, GGBFS was added as $0 \%, 10 \%$ and $20 \%$ of the total binder with variable activator content ( 40 and $35 \%$ ) and sodium silicate to sodium hydroxide ratio (1.5 to 2.5). Significant increase in strength and some decrease in the workability were observed in geopolymer concretes with higher GGBFS and lower sodium silicate to sodium hydroxide ratio in the mixtures. Similar to OPC concrete, development of tensile strength correlated well with the compressive strength of ambient-cured geopolymer concrete. The predictions of tensile strength from compressive strength of ambient-cured geopolymer concrete using the ACI 318 and AS 3600 codes tend to be similar to that for OPC concrete. The predictions are more conservative for heat-cured geopolymer concrete than for ambient-cured geopolymer concrete. 


\title{
The effects of ground granulated blast-furnace slag blending with fly ash and activator content on the workability and strength properties of geopolymer concrete cured at ambient temperature
}

\author{
Partha Sarathi Deb $^{\text {a,* }}$, Pradip Nath ${ }^{\mathrm{b}}$, Prabir Kumar Sarker ${ }^{\mathrm{c}}$ \\ a Department of Civil Engineering, Curtin University, GPO Box U1987, Perth, WA 6845, Australia. \\ email: partha.deb@postgrad.curtin.edu.au \\ ${ }^{\mathrm{b}}$ Department of Civil Engineering, Curtin University, GPO Box U1987, Perth, WA 6845, Australia. \\ email: pradip.nath@postgrad.curtin.edu.au \\ ${ }^{\mathrm{c}}$ Department of Civil Engineering, Curtin University, GPO Box U1987, Perth, WA 6845, Australia. \\ email: p.sarker@curtin.edu.au \\ *Corresponding author: Tel +61 89266 7568; Fax +61 89266 2681; \\ email: partha.deb@postgrad.curtin.edu.au
}

\begin{abstract}
Inclusion of ground granulated blast-furnace slag (GGBFS) with class F fly-ash can have a significant effect on the setting and strength development of geopolymer binders when cured in ambient temperature. This paper evaluates the effect of different proportions of GGBFS and activator content on the workability and strength properties of fly ash based geopolymer concrete. In this study, GGBFS was added as 0\%, 10\% and $20 \%$ of the total binder with variable activator content (40 and 35\%) and sodium silicate to sodium hydroxide ratio (1.5 to 2.5$)$. Significant increase in strength and some decrease in the workability were observed in geopolymer concretes with higher GGBFS and lower sodium silicate to sodium hydroxide ratio in the mixtures. Similar to OPC concrete, development of tensile strength correlated well with the compressive strength of ambient-cured geopolymer concrete. The
\end{abstract}


predictions of tensile strength from compressive strength of ambient-cured geopolymer concrete using the ACI 318 and AS 3600 codes tend to be similar to that for OPC concrete. The predictions are more conservative for heat-cured geopolymer concrete than for ambientcured geopolymer concrete.

Keywords: Ambient curing; geopolymer; ground granulated blast-furnace slag; fly ash; tensile strength; workability.

\section{Introduction}

Geopolymer concrete based on industrial by-product materials such as fly ash and slag can play a vital role in the context of sustainability and environmental issues [1]. Approximately $5 \%$ of global $\mathrm{CO}_{2}$ emissions originate from the manufacturing of Portland cement [2]. On the other hand, industrial by-product materials such as slag has been shown to release up to $80 \%$ less greenhouse gas emissions [3] and there are $80 \%$ to $90 \%$ less greenhouse gas emissions in the production of fly ash [4]. Therefore, a full replacement of OPC with GGBFS or fly ash would significantly reduce the $\mathrm{CO}_{2}$ emission of concrete production. Geopolymer concrete is an alternative concrete in which an alkali activated aluminosilicate material is used as the binder instead of the traditional cement binder. Thus the traditional binder based on cement or cement and other pozzolanic materials is replaced by the alkali activated inorganic binder in geopolymer concrete.

Geopolymers are very similar to zeolites and can be progressed through a series of several distinct reaction processes from initial pozzolanic activation to final microstructure development. The major processes involve the reaction between an aluminosilicate source such as fly ash, metakaolin or blast furnace slag and an alkaline solution which leads to final hardening of the matrix by exclusion of excess water and the growth of an inorganic polymer $[5,6,7]$. Previous studies indicated that the reaction of the selected pozzolanic material is the 
most significant factor in producing a mechanically sound binder via the geopolymerization process. The chemical reaction and the rate of strength development of geopolymer concrete are influenced by several factors based on chemical compositions of the source materials, alkaline activators and curing condition [8, 9, 10]. Islam et al. [11] reported that the compressive strength of geopolymer mortar increased with the increase of GGBS content in the binder containing fly ash and palm oil fuel ash. The inclusion of calcium from other sources such as calcium hydroxide in geopolymer based on metakaolin improved its mechanical strength [12]. Kumar [13] showed that mechanically activated fly ash based geopolymers display higher compressive strength due to the formation of a compact microstructure. Khale and Chaudhary [14] reported that the higher compressive strength values could be achieved in geopolymers after curing for five hours at $85^{\circ} \mathrm{C}$. However, the strength gain occurs at a much slower rate with age due to alkaline saturation and product densification [15].

Several previous studies reported the performance of geopolymer materials cured at high temperatures. These studies indicated that the heat-cured fly ash based geopolymer concrete developed high compressive and tensile strengths and low effective porosity, which are beneficial for concrete in an aggressive environment $[16,17,18,19]$. Heat-cured fly ash based geopolymer concrete showed better resistance to sea-water environment than OPC concrete of similar compressive strength [20]. It was shown in previous studies that the mechanical properties of heat-cured fly ash based geopolymer concrete are comparable to those of OPC based concrete and the methods of calculations used in the case of reinforced Portland cement concrete structures can be used to predict the strengths of reinforced geopolymer concrete structural members [21, 22, 23]. Sarker et al. [24] studied the fracture properties of heat cured geopolymer concrete. The experimental results showed higher 
fracture energy of heat-cured geopolymer concrete than OPC concrete of similar compressive strength.

Most of the previous studies were conducted on heat-cured geopolymer concrete that is considered to be ideal for precast concrete members. The development of geopolymer concrete without curing at elevated heat will widen its application to the areas beyond precast concrete members. Elimination of the elevated heat for curing will also reduce the cost and energy associated with the heat curing process. Workability and strength development are two important properties of concrete used in the determination of its suitability for casting and load carrying capacity of concrete members. Thus, the aim of this study is to investigate the effect of GGBFS blending with class F fly ash on the workability of fresh geopolymer concrete and the strength development with age when cured at ambient temperature. The scope of the work involved slump tests of fresh concrete and tensile and compressive strengths tests of hardened concrete specimens. Effects of the mix design variables of geopolymer concrete on these properties were studied. The correlation of the splitting tensile strength with compressive strength of the ambient-cured geopolymer concrete was compared with those of heat-cured geopolymer concrete and traditional water-cured OPC concrete.

\section{Experimental work}

\subsection{Materials}

Commercially available low calcium 'Class F' fly ash was used as the main binder. Ground granulated blast-furnace slag (GGBFS) was used as a partial replacement of fly ash in this study. The chemical compositions of the fly ash and GGBFS determined by X-Ray Fluorescence (XRF) are given in Table 1. The alkaline activator was a combination of sodium hydroxide and sodium silicate solutions. Sodium hydroxide solution of $14 \mathrm{M}$ concentration was prepared by mixing $97-98 \%$ pure pallets with tap water. The mass ratio of $\mathrm{SiO}_{2}$ to $\mathrm{Na}_{2} \mathrm{O}$ of the sodium silicate solution was $2.61\left(\mathrm{SiO}_{2}=30.0 \%, \mathrm{Na}_{2} \mathrm{O}=11.5 \%\right.$ and 
water $=58.5 \%$ ). Coarse aggregates were crushed granite with nominal maximum sizes of 7 , 10 and $20 \mathrm{~mm}$ that met the Australian Standard specifications. The final combined aggregate volume was a combination of $41 \%$ of $20 \mathrm{~mm}, 9 \%$ of $10 \mathrm{~mm}, 15 \%$ of $7 \mathrm{~mm}$ aggregates and $35 \%$ of sand. The physical properties of the materials are given in Table 2. A naphthalene based superplasticiser conforming to ASTM: C494-13 as Class A and F admixture was used in this study.

\subsection{Manufacture of geopolymer and OPC concretes}

The mixture proportions of ten geopolymer and two OPC concretes studied are given in Table 3. The concrete mixtures were proportioned based on the previous works on geopolymer concrete for ambient curing condition [25, 26, 27, 28]. The parameters studied were GGBFS content as a replacement of fly ash, alkaline activator content, and the sodium silicate to sodium hydroxide ratio $(\mathrm{SS} / \mathrm{SH})$ in the activator. Two series of geopolymer concrete mixtures with different amounts of alkaline activator were used in this study. In series A, four geopolymer mixtures were prepared with the activator content of $40 \%$ and varying the SS/SH ratio and the percentage of GGBFS. The quantity of aggregates was kept constant for all four mixtures in series A. In series B, six geopolymer concrete mixtures were prepared by reducing the alkaline activator content from $40 \%$ to $35 \%$. The slag content was 0,10 or $20 \%$ of the binder and the SS/SH ratio was 2.5 or 1.5 in the mixtures of series B.

The geopolymer concrete mixtures are designated by their variable constituents in the mixture. For example, A35 S20 R1.5 represents a geopolymer concrete mixture having alkaline activator solution (A) as $35 \%$ of the binder, GGBFS (S) as $20 \%$ of fly ash-GGBFS blend and sodium silicate to sodium hydroxide ratio $(\mathrm{R})$ of 1.5 . Water and superplasticiser were added to improve workability of some geopolymer concrete mixtures, as shown in Table 3. The OPC concrete mixtures were designed for two different strengths based on the guidelines of ACI 211.1-91 [29]. 


\subsection{Preparation, casting and curing of test specimens}

The aggregates were prepared to SSD condition before mixing of the concrete. The alkaline activator was prepared in the laboratory by mixing sodium silicate and sodium hydroxide solutions at the required ratio about 30 minutes before actual mixing of the concrete. Fly ash, GGBFS and aggregates were first dry-mixed together in a pan mixer. This was followed by addition of the activator solutions to the dry materials and the mixing continued further for about 5 minutes to produce fresh geopolymer concrete. Water and superplasticiser were added during mixing in the mixes of series B.

Geopolymer and OPC concrete cylinder specimens of $100 \mathrm{~mm}$ in diameter and 200 $\mathrm{mm}$ in height were cast. These specimens were used for compressive strength [30] test. Specimens of $150 \times 300 \mathrm{~mm}$ cylinders were cast for the splitting tensile strength [31] tests. All the specimens were compacted by using a table vibrator during casting. The geopolymer concrete specimens were cured in ambient condition at $20 \pm 2^{\circ} \mathrm{C}$ and $70 \pm 10 \%$ relative humidity and the OPC concrete specimens were cured in water at the same temperature.

\section{Test results and discussion}

\subsection{Workability}

Workability is the ease of working with a freshly mixed concrete in the stages of handling, placing, compacting and finishing. Slump test is used as a common test for measuring the workability of concrete. The workability of fresh geopolymer concrete was determined immediately after mixing of the concrete by the standard slump test in accordance with the ASTM: C $143-12$.

The spherical shape of fly ash particles combined with lubricating effect of the alkaline activator solution gives flowability of the fresh geopolymer concrete. Use of the sodium silicate $(\mathrm{SS})$ and sodium hydroxide $(\mathrm{SH})$ solutions, which are more viscous than water, usually makes geopolymer concrete more cohesive and sticky than OPC concrete. 
However, a higher slump of geopolymer concrete indicates a less stickiness and higher workability of the mixture.

The slump values of the geopolymer concrete mixtures are given in Table 4 and plotted in Figure 1. It can be seen from this figure that mixture R2.5S20 with $20 \%$ slag showed a slump value of $195 \mathrm{~mm}$ as compared to $250 \mathrm{~mm}$ slump showed by mixture R2.5S10 which had $10 \%$ slag. Similarly, mixture R1.5S20 with SS/SH ratio of 1.5 had a slump value of $180 \mathrm{~mm}$ as compared to $195 \mathrm{~mm}$ slump of mixture R2.5S20 with $\mathrm{SS} / \mathrm{SH}$ ratio of 2.5. Thus, the workability of the geopolymer concrete mixtures of series A showed decreasing trends with increase of the slag content and decrease of the SS/SH ratio. Mixture R1.5S20 exhibited the lowest slump value among all the geopolymer concrete mixtures of series A (Figure 1) since it had a higher percentage of slag (20\%) and a lower SS/SH ratio (1.5) as compared to the other mixtures.

The geopolymer concrete mixtures of series B were designed with reduced alkaline activator content (35\%) than those of series A (40\%). Preliminary mixtures with $35 \%$ alkaline liquid content showed poor workability as compared to the mixtures of series A when no extra water was added. Therefore, extra water $\left(8 \mathrm{~kg} / \mathrm{m}^{3}\right)$ and superplasticiser $\left(6 \mathrm{~kg} / \mathrm{m}^{3}\right)$ were added to the mixtures of series B in order to improve the workability. The slump values of the mixtures of series B (Figure 1 and Table 4) varied between $215 \mathrm{~mm}$ and $245 \mathrm{~mm}$. The mixtures were found to have reasonable workability during the casting time. When the amounts of extra water and superplasticiser remained same, the mixtures of series B showed decreasing trends of workability with the increase of slag content and decrease of the SS / SH ratio.

The slump values of the mixtures OPC1 and OPC2 were $105 \mathrm{~mm}$ and $150 \mathrm{~mm}$ respectively. Generally, when compared with the OPC concrete mixtures, the geopolymer concrete mixtures exhibited more cohesiveness than the OPC concrete mixtures. This is 
because of the inherent difference in the rheology of geopolymer matrix from that of OPC matrix, as described by Khale and Chaudhary [14]. No segregation or bleeding was observed in the mixtures during mixing, compaction and finishing of the concrete. The range of workability obtained in the geopolymer concrete mixtures of series A and B are considered suitable for casting of different concrete members such as beams, columns, slabs and footings. The slump values are in the range of the values reported by other researchers for geopolymer concrete using fly ash only [20, 23].

\subsection{Compressive strength}

Compressive strength is the most common property used to describe a concrete. Since other properties of concrete often correlate well with the compressive strength, it is used as an indicator of the other mechanical properties. The results of the compressive strength tests of geopolymer and OPC concrete samples are given in Table 4. These are the mean values of the results obtained from three identical specimens.

Figure 2 shows the compressive strength development of the geopolymer concrete mixtures of series A. The graphs show that the strength development of the geopolymer concrete mixtures slowed down after the age of 28 days and continued to increase at slower rates until 180 days of age. It can be seen in Figure 2 that the compressive strength of series A increased with the increase of GGBFS content in the mixtures. As shown in the figure, geopolymer concrete mixture R2.5S20 containing 20\% slag achieved $17 \%$ higher 28 -day compressive strength than R2.5S10 containing $10 \%$ slag. The effect of GGBFS at $20 \%$ replacement level on the increase of compressive strength appears to be more pronounced when the SS/SH ratio is reduced from 2.5 to 1.5 . With $20 \%$ GGBFS in the binder, the mixture with SS/SH ratio of 1.5 (R1.5S20) achieved 15\% higher 28-day compressive strength than the mixture with $\mathrm{SS} / \mathrm{SH}$ ratio of 2.5 (R2.5S20). Addition of more calcined source materials was reported to increase compressive strength by improving the microstructure of 
geopolymer matrix [33]. Thus the increase of compressive strength in the geopolymer concrete specimens by inclusion of GGBFS is attributed to the formation of more compact microstructure of the binder.

The strength development of the mixtures of series B with different slag contents and different SS/SH ratios are plotted in Figures 3 and 4. In this series, the activator content was reduced to $35 \%$ as compared to $40 \%$ in series A. Superplasticiser and extra water were added to improve the workability of these mixtures. In series B, mixture R2.5S00 with no slag in the binder developed strength at a slow rate. When GGBFS was incorporated in the mixture as a part of the binder with constant alkaline activator of $35 \%$ and $\mathrm{SS} / \mathrm{SH}$ ratio of 2.5 , the strength increased significantly. As shown in Figure 3, the compressive strength of geopolymer concrete increased from the early age of 7 days and continued to increase up to 180 days. At 28 days, mixtures R2.5S10 and R2.5S20 having $10 \%$ and $20 \%$ slag respectively, achieved higher strengths than the geopolymer concrete without slag (R2.5S00). The improvement of strength of slag blended fly ash based geopolymer concrete is due to the increase of calcium bearing compound in the dissoluted binder which produced a reaction product from both slag and fly ash [32]. As shown in Figure 4, the strength increase of geopolymer concrete mixtures R1.5S10 and R1.5S20 as compared to mixture R1.5S00 showed similar trends of $\mathrm{R} 2.5 \mathrm{~S} 10$ and $\mathrm{R} 2.5 \mathrm{~S} 20$ as compared to $\mathrm{R} 2.5 \mathrm{~S} 00$. It can be seen that the strength increase is more significant for $20 \%$ slag than for $10 \%$ slag in the binder. The highest strength increase at all ages up to 180 days was observed for $20 \%$ slag and SS/SH ratio of 1.5 .

All the geopolymer concrete samples showed increased compressive strength at higher slag contents in the mixtures. However, the compressive strength of geopolymer concrete is significantly influenced by the amount of water in the mixture. A decrease of compressive strength by the increase of water to solids ratio was also observed by Xi [15] and Wallah [16] for heat cured geopolymer concrete using fly ash only. Geopolymer concrete mixtures with 
extra water showed significant decrease in compressive strength for ambient cured geopolymer concrete. The effect of varying the water content in fly ash based geopolymer concrete has not been widely reported in the past. A comparison of the 28-day compressive strengths of the mixtures with and without water in series A and B is shown in Figure 5. A reduction of the activator liquid from $40 \%$ to $35 \%$ and addition of water to improve workability have increased the $\mathrm{H}_{2} \mathrm{O} / \mathrm{Na}_{2} \mathrm{O}$ ratio as shown in Table 4. For example, the $\mathrm{H}_{2} \mathrm{O} / \mathrm{Na}_{2} \mathrm{O}$ ratio increased from 11.745 in $\mathrm{R} 2.5 \mathrm{~S} 10$ (series A) to 12.764 in $\mathrm{R} 2.5 \mathrm{~S} 10$ (series B). The increase of this ratio eventually decreased the compressive strength of the mixtures of series B, as shown in Figure 5. Van Jaarsveld and van Deventer [33] reported that an increase of the water/fly ash ratio caused significant decrease of the strength in geopolymer paste specimens. A similar trend is shown by the results of the concrete specimens in this study. As shown by the strength-age graphs of Figures 3 to 5, the strength development rate of geopolymer concrete containing slag and cured at ambient temperature is similar to that of water-cured OPC concrete (Table 4). Generally, the 28-day strengths of the ambient-cured geopolymer concrete specimens of series A and B are considered suitable for various structural applications. These strengths are in the range of those of heat-cured fly ash geopolymer concrete obtained in previous studies [21, 23].

\subsection{Tensile strength}

Tensile strength of concrete is an important mechanical property that is used in many design aspects of concrete structures such as those related to initiation and propagation of cracks, shear and anchorage of reinforcing steel in concrete. Splitting tensile test is usually conducted to determine the tensile strength of concrete because of the simplicity of the test. The tensile strengths of the geopolymer and OPC concrete samples cured at ambient temperature were determined by conducting the splitting tensile strength tests in accordance with Australian Standard [31]. The results of the 28-day splitting tensile tests are given in 
Table 5. The tensile strengths of geopolymer concrete at 7, 28 and 90 days are plotted in Figures $6 \& 7$. It can be seen from these figures that tensile strength increased with the increase of age for all the mixtures. The results show that the tensile strength of concrete increased with the increase of slag content and decrease of SS/SH ratio in the mixtures of both series. This trend is similar to the trend shown by the development of compressive strength. In series A, geopolymer concrete mixture R1.5S20 with $20 \%$ GGBFS and SS/SH ratio of 1.5 gained $55 \%$ higher 28 -day tensile strength than $\mathrm{R} 2.5 \mathrm{~S} 10$ with $10 \%$ GGBFS and $\mathrm{SS} / \mathrm{SH}$ ratio of 2.5 .

In series $\mathrm{B}$, the tensile strength development of geopolymer concrete was relatively slow for the mixture with fly ash only as a binder (R2.5S00). However, the rate of tensile strength development increased significantly when GGBFS was incorporated in the mixture as a part of the binder. As shown in Figure 7, tensile strength increased from the early age of 7 days with the increase of slag content in the concrete. At 28 days, mixtures R2.5S10 and R2.5S20 having 10\% and 20\% GGBFS respectively, achieved $25 \%$ and $45 \%$ higher strength than R2.5S00. Comparing the tensile strengths of geopolymer mixtures R1.5S00, R1.5S10 and $\mathrm{R} 1.5 \mathrm{~S} 20$ with those of $\mathrm{R} 2.5 \mathrm{~S} 00, \mathrm{R} 2.5 \mathrm{~S} 10$ and $\mathrm{R} 2.5 \mathrm{~S} 20$ respectively, it can be seen that tensile strength was enhanced with the reduction of SS/SH ratio from 2.5 to 1.5.

The rate of tensile strength development of geopolymer concrete is affected by the amount of extra water in the mixtures. This is similar to the effect of water on the development of compressive strength as discussed before. Comparing the corresponding graphs for same slag content in Figures 6 and 7, it is seen that the tensile strength of the mixtures with reduced alkaline activator $(35 \%)$ are less than those of the mixtures with higher alkaline activator (40\%). This is because of the addition of extra water in the geopolymer mixtures with reduced alkaline activator. The 28-day tensile strengths of the similar mixes from both series containing $40 \%$ and $35 \%$ activator are plotted in Figure 8 . It can be seen 
from the figure that the largest difference of tensile strength is $28 \%$ which is for mixture $\mathrm{R} 1.5 \mathrm{~S} 20$ with $35 \%$ alkaline activator and extra water as compared to the mixture $\mathrm{R} 1.5 \mathrm{~S} 20$ (40\% alkaline activator with no extra water). The difference between the other corresponding mixtures is relatively small.

\subsection{Estimating tensile strength from compressive strength using design codes}

A correlation is usually observed between tensile strength and compressive strength of conventional OPC concrete. As shown in Table 5, the 28-day splitting tensile strength increased with the increase of compressive strength of the ambient-cured slag blended fly ash geopolymer concrete. The ratio of splitting tensile strength to compressive strength varied from 0.07 to 0.13 . This correlation tends to be similar to that shown by conventional watercured OPC concrete.

Because of the existence of a correlation between the tensile and compressive strengths, the tensile strength of OPC concrete is usually estimated by using a simple relationship given in terms of the compressive strength. The concrete structures design codes recommended such simple equations. The uniaxial or splitting tensile strengths are usually given in terms of the characteristic compressive strength in these equations with different coefficients and a power of the compressive strength. The Australian standard AS 3600 [34] recommends Equation 1 for OPC concrete at 28 days of age subjected to standard curing.

$$
f_{c t}{ }^{\prime}=0.36 \sqrt{ } f_{c}{ }^{\prime}
$$

where $f_{c t}$ ' and $f_{c}^{\prime}$ are the characteristic uniaxial tensile and compressive strengths respectively. In the absence of adequate data, the mean uniaxial tensile strength $\left(f_{c t m}\right)$ is obtained by multiplying the characteristic tensile strength by 1.4 . The uniaxial tensile strength is taken as 0.9 times the splitting tensile strength $\left(f_{c t . s p}\right)$ of concrete. The mean compressive strengths corresponding to characteristic strengths for different grades of concrete are given in the standard. For 25 to $65 \mathrm{MPa}$ grade concretes, the relationship between the characteristic 
compressive strength and the mean in-situ compressive strength $\left(f_{c m i}\right)$ is given by Equation 2 . The mean in-situ compressive strength $\left(f_{c m i}\right)$ shall be taken as $90 \%$ of the mean cylinder compressive strength $\left(f_{c m}\right)$.

$$
f_{c m i}=f_{c}^{\prime}+3.0(\mathrm{MPa})
$$

The ACI 318 code [35] recommends Equation 3 as the approximate relationship between the mean splitting tensile strength and the characteristic compressive strength. The relationships between the mean and characteristic compressive strengths are given by equations 4 to 6 .

$$
\begin{aligned}
& f_{c t . s p}=0.56 \sqrt{ } f_{c}, \\
& f_{c m}=f_{c}{ }^{\prime}+7.0(\mathrm{MPa}) \text { for } f_{c}{ }^{\prime}<21 \mathrm{MPa} \\
& f_{c m}=f_{c}{ }^{\prime}+8.3(\mathrm{MPa}) \text { for } 21<f_{c}^{\prime} \leq 35 \mathrm{MPa} \\
& f_{c m}=1.1 f_{c}{ }^{\prime}+5.0(\mathrm{MPa}) \text { for } f_{c}^{\prime}>35 \mathrm{MPa}
\end{aligned}
$$

The Australian standard (Equations 1 and 2) and the ACI code (Equations 3 to 6) were used to calculate the splitting tensile strengths of the concretes. The splitting tensile strengths calculated using the 28-day compressive strengths and the ratios of the experimentally determined value to the calculated value are given in Table 5. These ratios obtained for the AS 3600 and ACI 318 codes are plotted in Figures 9 and 10 respectively. Tensile strengths of heat-cured fly ash geopolymer concrete from previous research [22] and those of OPC concrete of this study and another study [36] are also included in these figures for comparison.

It can be seen from Figures 9 and 10 that the test to prediction ratios of the ambientcured geopolymer concrete tend to be similar to that of the water-cured OPC concrete for 
predictions by both AS 3600 [34] and ACI 318 [35] methods. The trends of the test to prediction ratios are found to be higher for the heat-cured geopolymer concrete than for the ambient-cured geopolymer and water-cured OPC concretes. Generally, the predictions by the ACI 318 (Figure 10) are found to be more conservative than those of by the AS 3600 (Figure 9).

\section{Conclusions}

The effects of blending GGBFS with class F fly ash in the binder of geopolymer concrete cured at ambient temperature were studied by using an experimental work. Effects of the other mixture variables such as the activator liquid content and SS/SH ratio in the binder were also investigated. Workability of the fresh mixtures and development of compressive and tensile strengths were determined. The suitability of using the relationships between tensile and compressive strengths given for OPC concrete in the AS 3600 and ACI 318 codes was investigated for the ambient and heat-cured geopolymer concretes. The correlations obtained for the ambient-cured geopolymer concrete were compared with those of the heatcured geopolymer concrete and water-cured OPC concrete. The following conclusions are drawn from the study:

- Workability of geopolymer concrete decreased with the increase of GGBFS content together with fly ash in the binder when the other mixture variables remained the same. This is mainly because of the accelerated reaction of the calcium and the angular shape of the slag as compared to the spherical shape of the fly ash particles. The addition of GGBFS enhanced setting of the concrete at ambient temperature. Workability also decreased with the reduction of the activator to binder ratio from 0.4 to 0.35 . Addition of extra water improved workability at the cost of strength. 
- Compressive strength at all ages up to 180 days increased with the increase of the slag content. Strength development of the slag blended fly ash geopolymer concrete cured at ambient temperature was similar to that of water-cured OPC concrete. The strength gain slowed down after the age of 28 days and continued to increase at a slower rate until 180 days. The 28-day compressive strength reached up to $51 \mathrm{MPa}$ in geopolymer concrete containing $20 \%$ slag and $80 \%$ fly ash in the binder and $40 \%$ activator liquid with SS / SH ratio of 1.5 when cured at $20^{\circ} \mathrm{C}$.

- Tensile strength of ambient cured geopolymer concrete increased with the increase of compressive strength. The effect of the mixture variables on the development of tensile strength was similar to that on the development of compressive strength. The methods of estimating the splitting tensile strength from compressive strength of OPC concrete recommended in the AS 3600 and ACI 318 design codes resulted in similar predictions for the ambient-cured slag blended fly ash geopolymer concrete and OPC concrete. The predictions were generally more conservative for heat-cured geopolymer concrete than those for the ambient-cured geopolymer and OPC concretes.

\section{Acknowledgments}

The authors wish to gratefully acknowledge the support of Coogee Chemicals regarding supply the chemicals used in this study. The discussions with Professor Vijaya Rangan of Curtin University are gratefully acknowledged. 


\section{Reference}

1. Duxson P, Fernández-Jiménez A, Provis JL, Lukey GC, Palomo A, van Deventer JSJ. Geopolymer technology: the current state of the art. J. Mater. Sci 2007; 42 (9): 29172933.

2. Lawrence CD. The Production of Low-Energy Cements. In: HEWEIT, P, C (Eds.), Lea's. Chemistry of Cement and Concrete, Oxford: Butterworth-Heinemann; 1998, p. $421-470$.

3. Roy DM, Idorn GM. Hydration, Structure, and Properties of Blast- Furnace Slag Cements, Mortars, and Concrete. J. Amer Conc Inst 1982; 79(6): 444-457.

4. Duxson P, Lukey G, van Deventer JSJ. Physical evolution of geopolymer derived from metakaolin up to $1000{ }^{\circ} \mathrm{C}$. J. Mater Sci 2007; 42(9): 3044-3054.

5. Davidovits J. Geoplolymer chemistry and application. 2nd edition. France: Institute Geopolymer Saint-Quentin; 2008.

6. Davidovits J. High alkali cements for 21 st century concretes, concrete technology, past, present, and future. P.K. Mehta Ed. American Concrete Institute; 1994, p. 383-397.

7. Shi C, Krivenko PV, Roy DM. Alkali-activated cements and concretes. UK: Taylor \& Francis; 2006.

8. Diaz EI, Allouche EN, Eklund S. Factors affecting the suitability of fly ash as source materials for geopolymers. Fuel 2010; 89: 992-996.

9. Yip CK, Lukey GC, Provis JL, van Deventer JSJ. Effect of calcium silicate sources on geopolymerization. Cem Concr Res 2008; 38: 554-64.

10. Wang K, Shah S, Mishulovich A. Effects of curing temperature and $\mathrm{NaOH}$ addition on hydration and strength development of clinker-free CKD-fly ash binders. Cem Concr Comps 2004; 34 (2): 299-309. 
11. Islam A, Alengaram UJ, Jumaat MZ, Bashar II. The development of compressive strength of ground granulated blast furnace slag-palm oil fuel ash-fly ash based geopolymer mortar. Mater Des 2014; 56: 833-841.

12. Bernal SA, Rodríguez ED, Mejía de Gutiérrez R, Gordillo M, Provis JL, Mechanical and thermal characterisation of geopolymers based on silicate-activated metakaolin/slag blends. J Mater Sci 2011; 42:5477-5486.

13. Kumar S, Kumar R, Alex TC, Bandopadhyay A, Mehrotra SP. Effect of mechanically activated fly ash on the properties of geopolymer cement. In: Davidovits, J. (Ed.), Proceedings of the World Congress Geopolymer; 2005.

14. Khale D, Chaudhary R. Mechanism of Geopolymerization and Factors Influencing Its Development: A Review. J Mater Sci 2007; 42:729-746.

15. Xi Z, Xi Y. Hardening Mechanisms of an Alkaline-Activated Class F FlyAsh. Cem Concr Res 2001; 31:1245-1249.

16. Wallah SE, Rangan BV. Low calcium fly ash based geopolymer concrete: long term properties. Perth, Australia: Faculty of Engineering, Curtin University; 2006.

17. Palomo A, Grutzeck MW, Blanco MT. Alkali-activated fly ashes a cement for the future. Cem Concr Res 1999; 29:1323-1329.

18. Bakharev T. Durability of geopolymer materials in sodium and magnesium sulphate solutions. Cem Concr Res 2005; 35:1233- 1246.

19. Ramlochan T, Zacarias P, Thoas MDA, Hooton RD. The effect of pozzolans and slag on the expansion of mortars cured at elevated temperature: Part I: Expansive behaviour. Cem Concr Res 2003; 33 (6):807-814.

20. Olivia M, Nikraz, HR. Properties of fly ash geopolymer concrete designed by Taguchi method. Mater Des 2012; 36: 191-198 
21. Sofi M, van Deventer JSJ, Mendis PA, Lukey GC. Bond performance of Reinforcing Bars in Inorganic Polymer Concrete (IPC). J Mate Sci 2007; 42: 3107-3116.

22. Sarker PK, Grigg A, Chang EH. Bond Strength of Geopolymer Concrete with Reinforcing Steel. in: Zingoni A, editors. Proceedings of Recent Development in Structural Engineering, Mechanics and Computation, Netherlands: 2007, 1315-1320.

23. Chang EH. Shear and Bond Behaviour of Reinforced Fly Ash-based Geopolymer Concrete Beams. PhD Thesis. Perth, Australia: Faculty of Engineering, Curtin University; 2009.

24. Sarker PK, Haque R, Ramgolam KV. Fracture behaviour of heat cured fly ash based geopolymer concrete. Mater Des 2013; 44: 580-586.

25. Nath P, Sarker PK. Geopolymer Concrete for ambient Curing Condition. Proceedings of Australasian Structural Engineering Conference. Perth, Australia; 2012.

26. Deb PS, Nath P, Sarker PK. Strength and Permeation Properties of Slag Blended Fly Ash Based Geopolymer Concrete. Adv Mater Res 2013; 651:168-173.

27. Deb PS, Nath P, Sarker PK. Properties of fly ash and slag blended geopolymer concrete cured at ambient temperature. $7^{\text {th }}$ International Structural Engineering and Construction Conference. Honolulu, USA; 2013.

28. Deb PS, Nath P, Sarker PK. Properties of Slag Blended Fly Ash Based Geopolymer Concrete in Aggressive Environment. 26 ${ }^{\text {th }}$ Biennial Concrete Institute of Australia's National Conference; 2013.

29. American Concrete Institute. Standard Practice for Selecting Proportions for Normal Heavyweight and Mass concrete. ACI211.1; 1991.

30. Standard Australia. Methods of testing concrete - Determination of the compressive strength of concrete specimens. AS $1012.9 ; 1999$ 
31. Standard Australia. Methods of testing concrete - Determination of indirect tensile strength of concrete cylinders. AS 1012.10; 2000.

32. Phoo-Ngernkham T, Chindaprasirt P, Sata V, Sinsiri T. High calcium fly ash geopolymer containing diatomite as additive. Ind J Eng Mate Sci 2013; 20(4):310-318.

33. Van Jaarsveld JGS, van Deventer JSJ, Lukey GC. The effect of composition and temperature on the properties of fly ash- and kaolinite-based geopolymers. Chem Engg J 2002; 89(1-3): 63-73.

34. Standard Australia. Concrete structures. AS 3600; 2009.

35. American Concrete Institute. Building Code Requirements for Structural Concrete and Commentary. ACI318; 2008.

36. Vasile R. Bond strengths of geopolymer and OPC concretes. Final Year Project. Perth, Australia: Faculty of Engineering, Curtin University; 2009. 


\section{List of tables:}

Table 1: Chemical compositions of fly ash and GGBFS

Table 2: Physical properties of materials

Table 3: Mixture proportions concrete

Table 4: Mix design parameters and compressive strength results

Table 5: Test and calculated tensile strengths of concrete. 


\section{List of figures:}

Fig. 1. Slump of different geopolymer concrete with different slag content.

Fig. 2. Compressive strength variation of geopolymer concrete in Series A

Fig. 3. Compressive strength variation of geopolymer concrete with different slag content and SS/SH ratio 2.5 of series B

Fig. 4. Compressive strength variation of geopolymer concrete with different slag content and SS/SH ratio 1.5 of series B

Fig. 5. Change in compressive strength for added water in geopolymer concrete mixtures.

Fig. 6. Splitting tensile strength of geopolymer concrete (Series A, $40 \%$ activator).

Fig. 7. Splitting tensile strength of geopolymer concrete (Series B, 35\% activator + water)

Fig. 8. Change in Tensile strength for added water in geopolymer concrete mixtures.

Fig. 9. Ratio of experimental to calculated split tensile strengths of geopolymer concrete by AS3600

Fig.10. Ratio of experimental to calculated split tensile strengths of geopolymer concrete by ACI 318 
Table 1: Chemical compositions of fly ash and GGBFS

\begin{tabular}{cccccccccccc}
\hline $\begin{array}{c}\text { Sample } \\
(\%)\end{array}$ & $\mathrm{SiO}_{2}$ & $\mathrm{Al}_{2} \mathrm{O}_{3}$ & $\mathrm{Fe}_{2} \mathrm{O}_{3}$ & $\begin{array}{c}\mathrm{SiO}_{2+} \mathrm{Al}_{2} \mathrm{O}_{3+} \\
\mathrm{Fe}_{2} \mathrm{O}_{3}\end{array}$ & $\mathrm{CaO}$ & $\mathrm{Na}_{2} \mathrm{O}$ & $\mathrm{K}_{2} \mathrm{O}$ & $\mathrm{SO}_{3}$ & $\mathrm{P}_{2} \mathrm{O}_{5}$ & $\mathrm{TiO}_{2}$ & $\mathrm{LOI}^{\mathrm{a}}$ \\
\hline Fly ash & 53.71 & 27.20 & 11.17 & 92.08 & 1.90 & 0.36 & 0.54 & 0.30 & 0.71 & 1.62 & 0.68 \\
GGBFS & 29.96 & 12.25 & 0.52 & - & 45.45 & 0.31 & 0.38 & 3.62 & 0.04 & 0.46 & 2.39 \\
\hline \multicolumn{2}{l}{${ }^{\mathrm{a}}$ Loss on ignition }
\end{tabular}

${ }^{\mathrm{a}}$ Loss on ignition 
Table 2: Physical properties of materials

\begin{tabular}{lcccc}
\hline Materials & Fly ash & SS & CA & FA \\
\hline Specific gravity & 2.64 & 1.458 & - & 2.62 \\
Fineness modulus & - & - & 6.12 & 1.97 \\
Bulk density $\left(\mathrm{kg} / \mathrm{m}^{3}\right)$ & - & - & 1686.8 & 1645.2 \\
\hline${ }^{\mathrm{a}}$ Sodium silicate ${ }^{\mathrm{b}}{ }^{\mathrm{b}}$ Coarse aggregate, ${ }^{\mathrm{c}}$ Fine aggregate & &
\end{tabular}


Table 3: Mixture proportions concrete

\begin{tabular}{|c|c|c|c|c|c|c|c|c|c|c|c|c|}
\hline \multirow[b]{2}{*}{ Mixture } & \multicolumn{4}{|c|}{ Series A } & \multicolumn{6}{|c|}{ Series B } & \multirow[b]{2}{*}{ OPC1 } & \multirow[b]{2}{*}{ OPC2 } \\
\hline & GPC1 & GPC2 & GPC3 & GPC4 & GPC5 & GPC6 & GPC7 & GPC8 & GPC9 & GPC10 & & \\
\hline Label & $\begin{array}{c}\text { A40 } \\
\text { S10 } \\
\text { R2.5 }\end{array}$ & $\begin{array}{c}\mathrm{A} 40 \\
\mathrm{~S} 20 \\
\mathrm{R} 2.5\end{array}$ & $\begin{array}{c}\mathrm{A} 40 \\
\mathrm{~S} 10 \\
\mathrm{R} 1.5\end{array}$ & $\begin{array}{c}\text { A40 } \\
\text { S20 } \\
\text { R1.5 }\end{array}$ & $\begin{array}{c}\text { A35 } \\
\text { S00 } \\
\text { R2.5 }\end{array}$ & $\begin{array}{c}\text { A35 } \\
\text { S10 } \\
\text { R2.5 }\end{array}$ & $\begin{array}{c}\text { A35 } \\
\text { S20 } \\
\text { R2.5 }\end{array}$ & $\begin{array}{l}\text { A35 } \\
\text { S00 } \\
\text { R1.5 }\end{array}$ & $\begin{array}{c}\text { A35 } \\
\text { S10 } \\
\text { R1.5 }\end{array}$ & $\begin{array}{c}\text { A35 } \\
\text { S20 } \\
\text { R1.5 }\end{array}$ & . & 然 \\
\hline $\mathrm{CA}^{\mathrm{a}}$ & 1209 & 1209 & 1209 & 1209 & 1222 & 1216 & 1216 & 1222 & 1216 & 1216 & 1054 & 1054 \\
\hline Sand & 651 & 651 & 651 & 651 & 658 & 655 & 655 & 658 & 655 & 655 & 768 & 740 \\
\hline Fly ash & 360 & 320 & 360 & 320 & 400 & 360 & 320 & 400 & 360 & 320 & - & - \\
\hline GGBFS & 40 & 80 & 40 & 80 & 0 & 40 & 80 & 0 & 40 & 80 & - & - \\
\hline Cement & - & - & - & - & - & - & - & - & - & - & 446 & 366.4 \\
\hline $\mathrm{SH}^{\mathrm{b}}$ & 45.7 & 45.7 & 64 & 64 & 40 & 40 & 40 & 56 & 56 & 56 & - & - \\
\hline $\mathrm{SS}^{\mathrm{c}}$ & 114.3 & 114.3 & 96 & 96 & 100 & 100 & 100 & 84 & 84 & 84 & - & - \\
\hline Water & - & - & - & - & - & 8 & 8 & - & 8 & 8 & 165 & 201.6 \\
\hline $\mathrm{SP}^{\mathrm{d}}$ & - & - & - & - & 6 & 6 & 6 & 6 & 6 & 6 & - & - \\
\hline
\end{tabular}

${ }^{\mathrm{a}}$ Coarse aggregate, ${ }^{\mathrm{b}}$ Sodium hydroxide, ${ }^{\mathrm{c}}$ Sodium silicate, ${ }^{\mathrm{d}}$ Superplasticiser 
Table 4: Mix design parameters and compressive strength results

\begin{tabular}{|c|c|c|c|c|c|c|c|c|}
\hline \multirow{2}{*}{\multicolumn{2}{|c|}{ Mixtures }} & \multirow{2}{*}{$\begin{array}{c}\mathrm{H}_{2} \mathrm{O} \\
/ \mathrm{Na}_{2} \mathrm{O}\end{array}$} & \multirow{2}{*}{$\begin{array}{l}\text { Slump } \\
(\mathrm{mm})\end{array}$} & \multicolumn{5}{|c|}{ Compressive Strength (MPa) } \\
\hline & & & & 7 day & 28 day & 56 day & 90 day & 180 day \\
\hline \multirow{4}{*}{ A $(40 \%)$} & $\mathrm{R} 2.5 \mathrm{~S} 10$ & 11.745 & 250 & 27.0 & 40.0 & 45.0 & 47.0 & 49.0 \\
\hline & $\mathrm{R} 2.5 \mathrm{~S} 20$ & 11.758 & 195 & 31.0 & 47.0 & 50.0 & 54.0 & 59.0 \\
\hline & $\mathrm{R} 1.5 \mathrm{~S} 10$ & 10.628 & 210 & 25.0 & 43.0 & 50.0 & 52.0 & 54.0 \\
\hline & $\mathrm{R} 1.5 \mathrm{~S} 20$ & 10.639 & 180 & 29.0 & 54.0 & 63.0 & 68.0 & 70.0 \\
\hline \multirow{8}{*}{$\mathrm{B}(35 \%)$} & $\mathrm{R} 2.5 \mathrm{~S} 00$ & 11.656 & 245 & 11.0 & 25.0 & 30.0 & 33.0 & 35.0 \\
\hline & $\mathrm{R} 2.5 \mathrm{~S} 10$ & 12.764 & 230 & 15.0 & 27.0 & 35.0 & 38.0 & 39.0 \\
\hline & $\mathrm{R} 2.5 \mathrm{~S} 20$ & 12.781 & 215 & 22.0 & 35.0 & 40.0 & 43.0 & 44.0 \\
\hline & $\mathrm{R} 1.5 \mathrm{~S} 00$ & 10.558 & 235 & 8.0 & 27.0 & 32.0 & 34.0 & 37.0 \\
\hline & $\mathrm{R} 1.5 \mathrm{~S} 10$ & 11.540 & 245 & 14.0 & 27.0 & 35.0 & 41.0 & 44.0 \\
\hline & $\mathrm{R} 1.5 \mathrm{~S} 20$ & 11.553 & 220 & 25.0 & 45.0 & 52.0 & 54.0 & 57.0 \\
\hline & OPC1 & - & 105 & 36.0 & 48.0 & 56.0 & 62.0 & 65.0 \\
\hline & OPC2 & - & 150 & 23.0 & 33.0 & 37.0 & 40.0 & 43.0 \\
\hline
\end{tabular}

${ }^{\mathrm{a}}$ Water to solid ratio 
Table 5: Test and calculated tensile strengths of concrete.

\begin{tabular}{|c|c|c|c|c|c|c|c|c|}
\hline \multirow[b]{2}{*}{ Series } & \multirow[b]{2}{*}{ Label } & \multicolumn{3}{|c|}{ 28-day strength $(\mathrm{MPa})$} & \multicolumn{2}{|c|}{$\begin{array}{l}\text { Calc. split tensile } \\
\text { strength }(\mathrm{MPa})\end{array}$} & \multicolumn{2}{|c|}{$\begin{array}{l}\text { Ratio of test to } \\
\text { calc. split tensile } \\
\text { strengths }(\mathrm{MPa})\end{array}$} \\
\hline & & $\begin{array}{l}\text { Compr. } \\
f_{\mathrm{cm}} \\
(\mathrm{MPa})\end{array}$ & $\begin{array}{l}\text { Split } \\
\text { tensile, } \\
\text { fct.sp } \\
(\mathrm{MPa})\end{array}$ & $\begin{array}{l}f_{c t . s p} \\
f_{c m} \\
\text { ratio }\end{array}$ & $\begin{array}{c}\text { AS } \\
3600\end{array}$ & $\begin{array}{l}\text { ACI } \\
318\end{array}$ & $\begin{array}{c}\text { AS } \\
3600\end{array}$ & $\begin{array}{l}\text { ACI } \\
318\end{array}$ \\
\hline \multirow{4}{*}{$\begin{array}{c}\text { A } \\
(40 \%)\end{array}$} & S10 R2.5 & 37 & 3.09 & 0.08 & 3.2 & 3.1 & 0.96 & 0.98 \\
\hline & $\mathrm{S} 20 \mathrm{R} 2.5$ & 44 & 3.25 & 0.07 & 3.5 & 3.4 & 0.93 & 0.94 \\
\hline & S10 R1.5 & 40 & 2.88 & 0.07 & 3.3 & 3.3 & 0.86 & 0.88 \\
\hline & S20 R1.5 & 51 & 4.81 & 0.09 & 3.8 & 3.7 & 1.27 & 1.29 \\
\hline \multirow{6}{*}{$\begin{array}{c}\mathrm{B} \\
(35 \%)\end{array}$} & S00 R2.5 & 22 & 2.12 & 0.10 & 2.5 & 2.3 & 0.86 & 0.93 \\
\hline & S10 R2.5 & 24 & 2.68 & 0.11 & 2.6 & 2.4 & 1.04 & 1.11 \\
\hline & $\mathrm{S} 20 \mathrm{R} 2.5$ & 32 & 3.02 & 0.09 & 3.0 & 2.9 & 1.01 & 1.04 \\
\hline & S00 R1.5 & 24 & 2.27 & 0.09 & 2.6 & 2.4 & 0.88 & 0.94 \\
\hline & S10 R1.5 & 24 & 3.03 & 0.13 & 2.6 & 2.4 & 1.17 & 1.25 \\
\hline & $\mathrm{S} 20 \mathrm{R} 1.5$ & 42 & 3.75 & 0.09 & 3.4 & 3.3 & 1.09 & 1.11 \\
\hline \multirow{2}{*}{$\mathrm{OPC}$} & OPC1 & 45 & 4.15 & 0.09 & 3.6 & 3.5 & 1.15 & 1.19 \\
\hline & OPC2 & 30 & 3.43 & 0.11 & 2.9 & 2.8 & 1.18 & 1.23 \\
\hline
\end{tabular}




\section{List of figures:}

Fig. 1. Slump of different geopolymer concrete with different slag content.

Fig. 2. Compressive strength variation of geopolymer concrete in Series A

Fig. 3. Compressive strength variation of geopolymer concrete with different slag content and SS/SH ratio 2.5 of series B

Fig. 4. Compressive strength variation of geopolymer concrete with different slag content and SS/SH ratio 1.5 of series B

Fig. 5. Change in compressive strength for added water in geopolymer concrete mixtures.

Fig. 6. Splitting tensile strength of geopolymer concrete (Series A, $40 \%$ activator).

Fig. 7. Splitting tensile strength of geopolymer concrete (Series B, 35\% activator + water)

Fig. 8. Change in Tensile strength for added water in geopolymer concrete mixtures.

Fig. 9. Ratio of experimental to calculated split tensile strengths of geopolymer concrete by AS3600

Fig.10. Ratio of experimental to calculated split tensile strengths of geopolymer concrete by ACI 318 
Figure 1

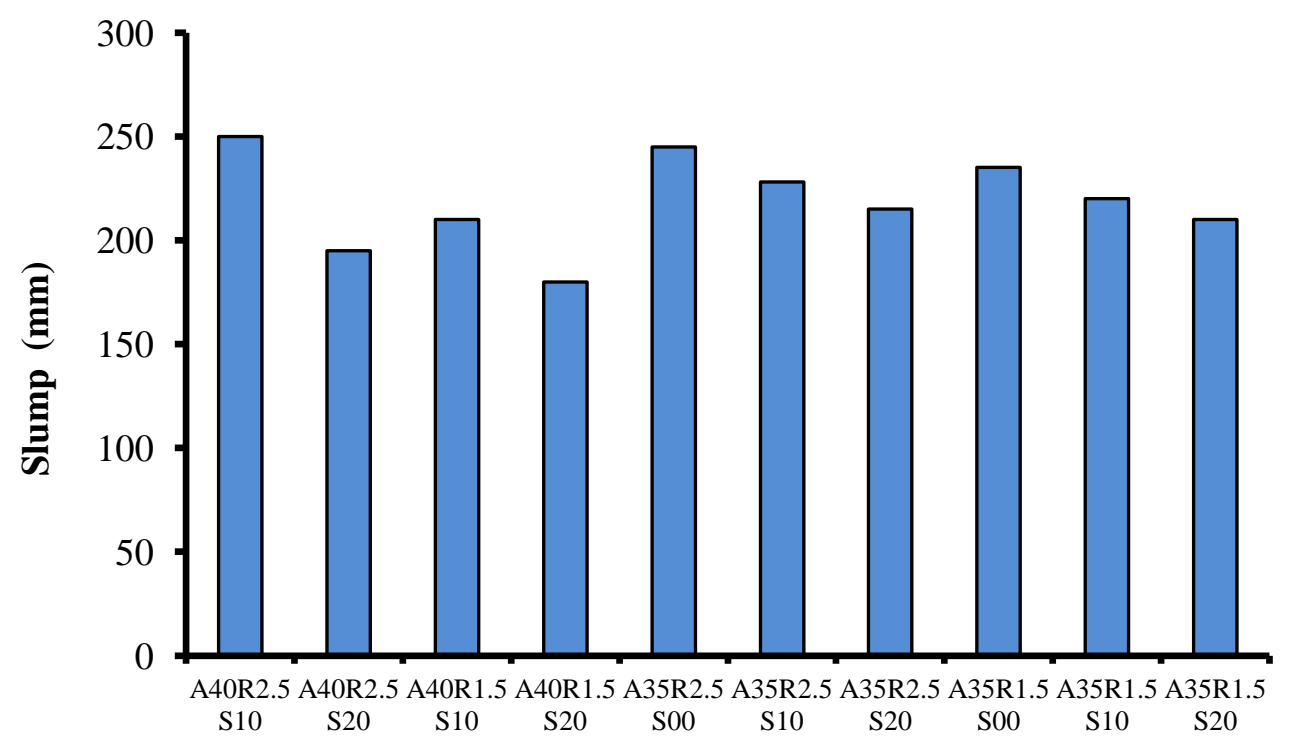

Fig. 1. Slump of different geopolymer concrete with different slag content. 
Figure 2

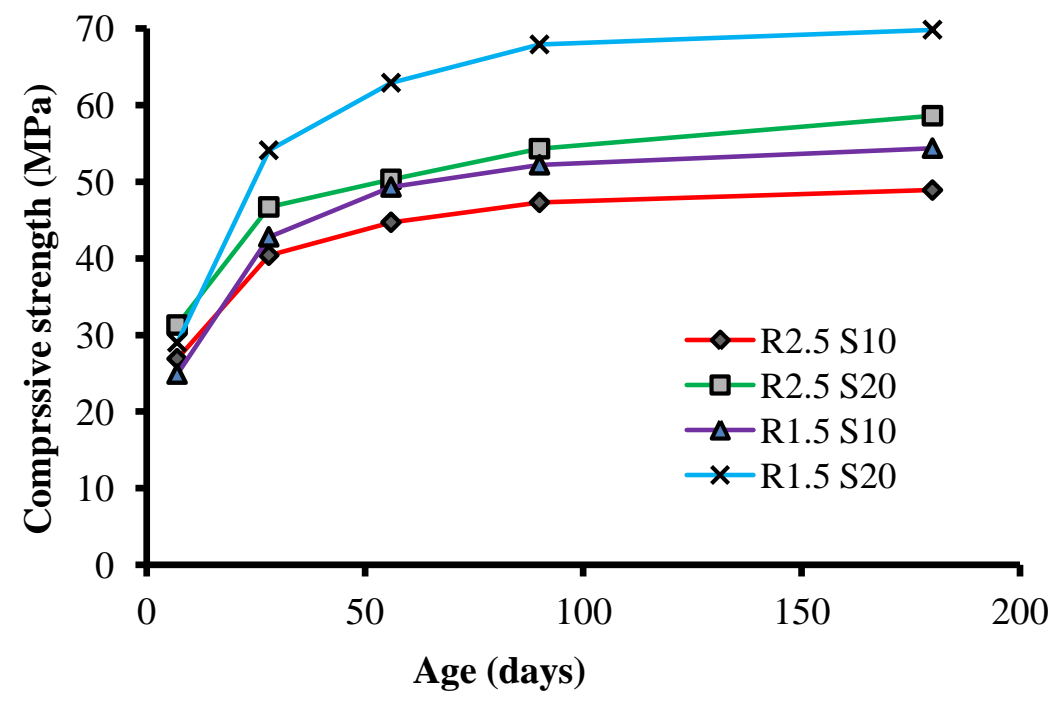

Fig. 2. Compressive strength variation of geopolymer concrete in Series A 
Figure 3

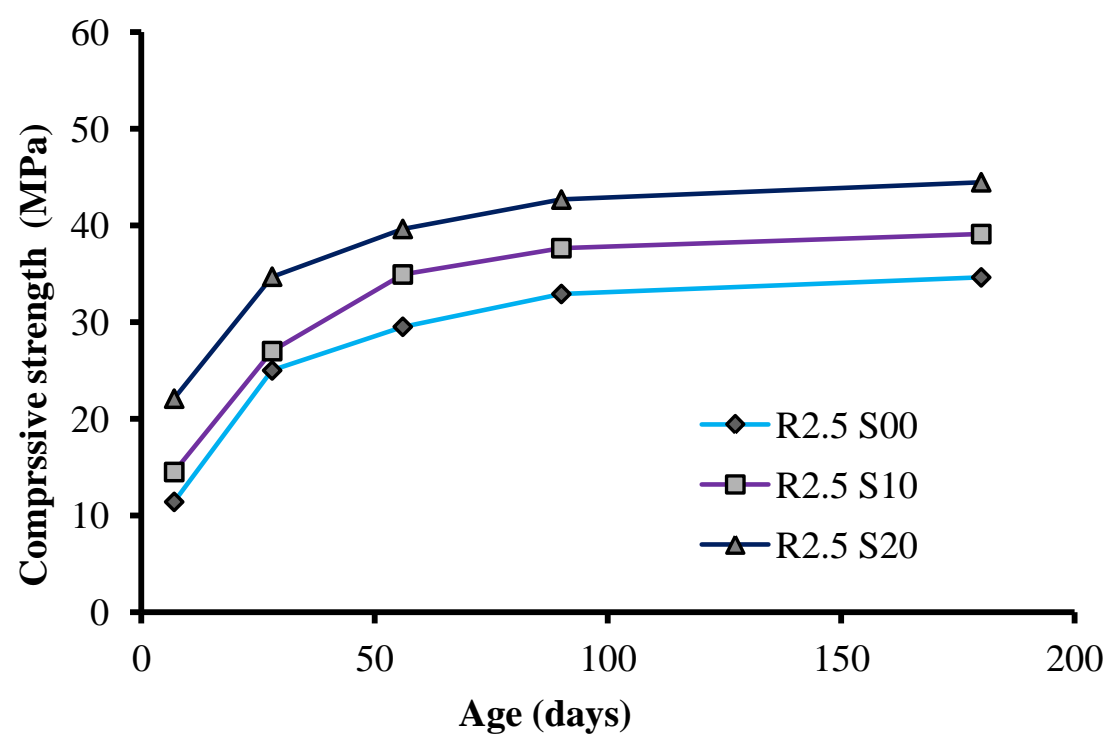

Fig. 3. Compressive strength variation of geopolymer concrete with different slag content and SS/SH ratio 2.5 of series $B$ 
Figure 4

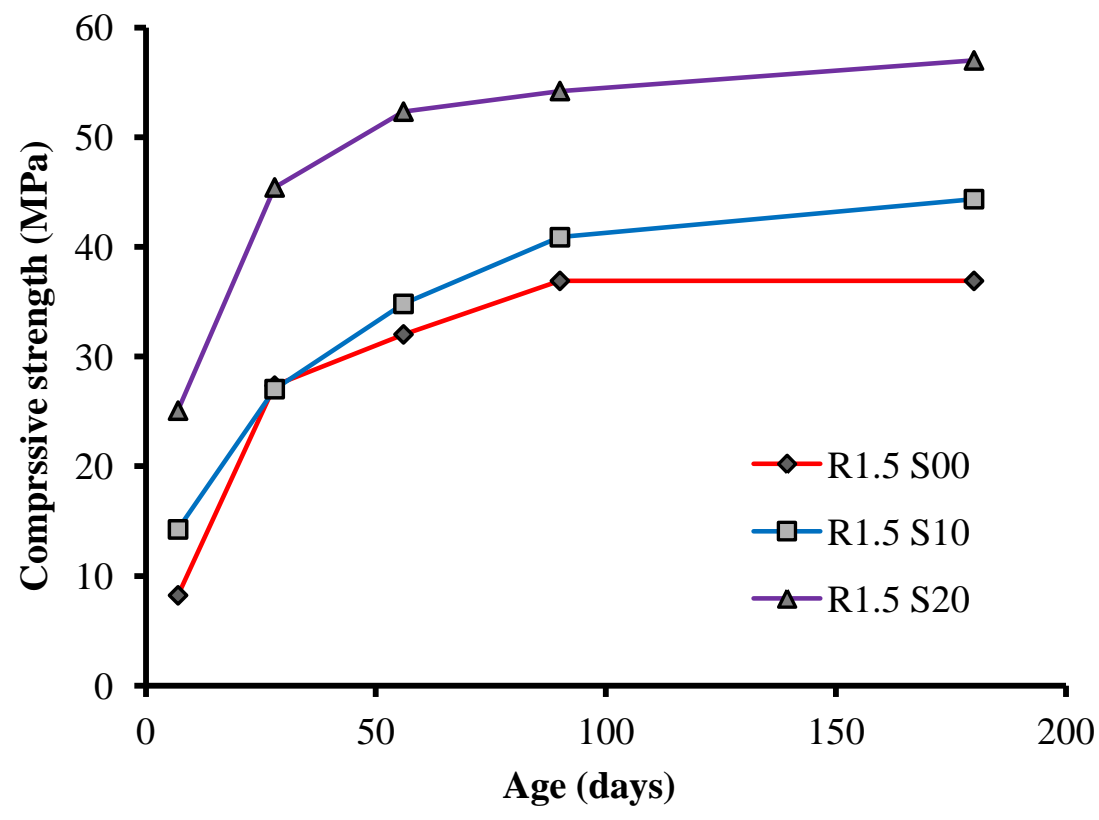

Fig. 4. Compressive strength variation of geopolymer concrete with different slag content and $\mathrm{SS} / \mathrm{SH}$ ratio 1.5 of series $\mathrm{B}$ 
Figure 5

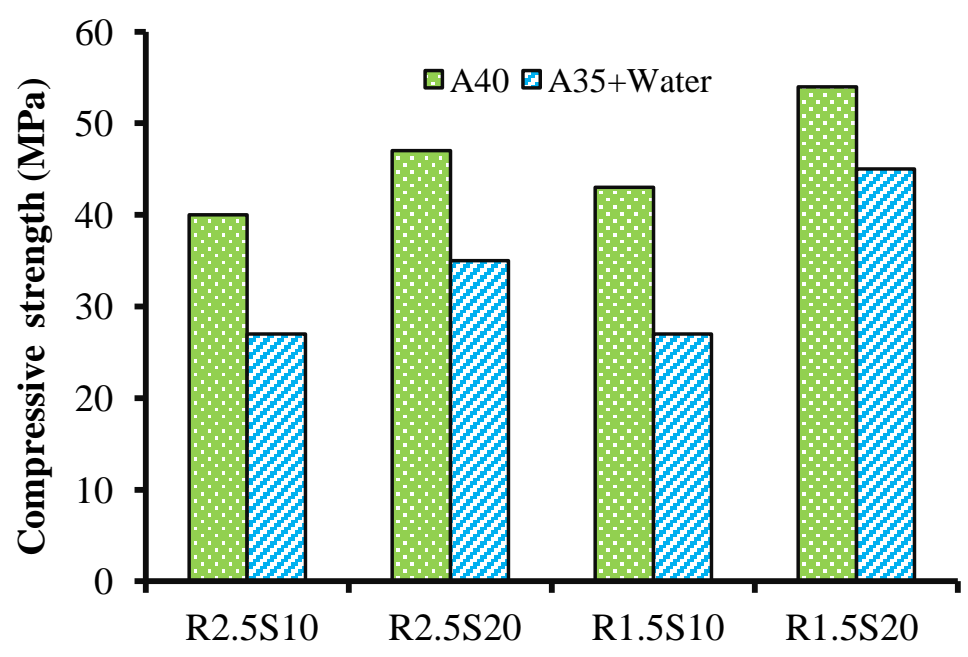

Fig. 5. Change in compressive strength for added water in geopolymer concrete mixtures. 
Figure 6

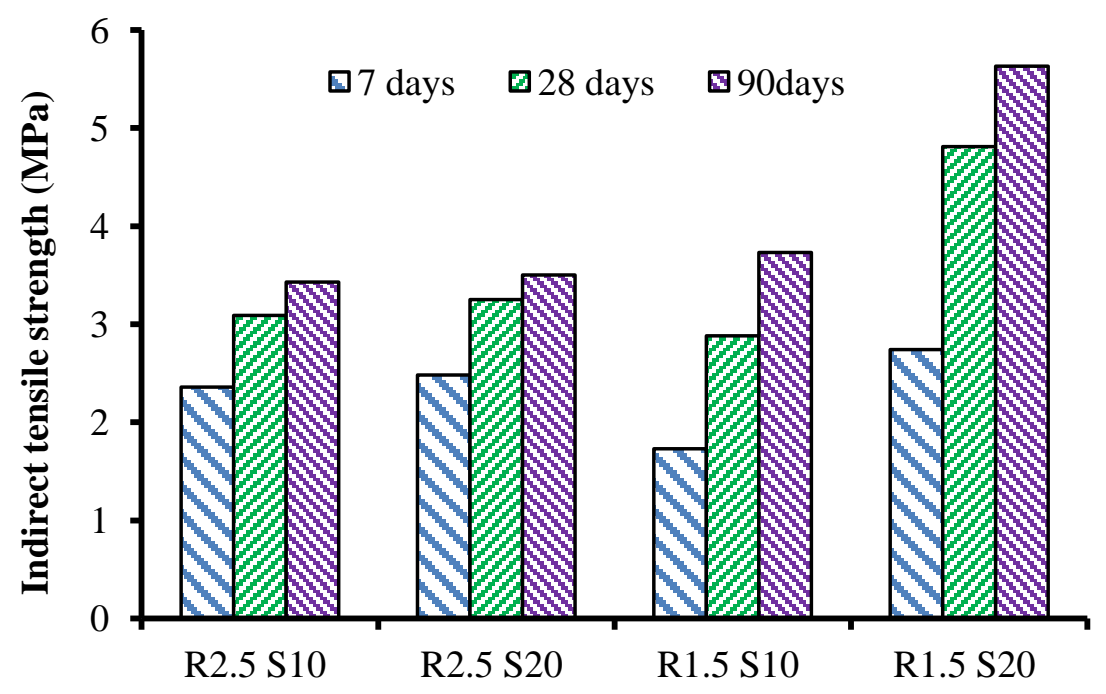

Fig. 6. Splitting tensile strength of geopolymer concrete (Series A, 40\% activator). 


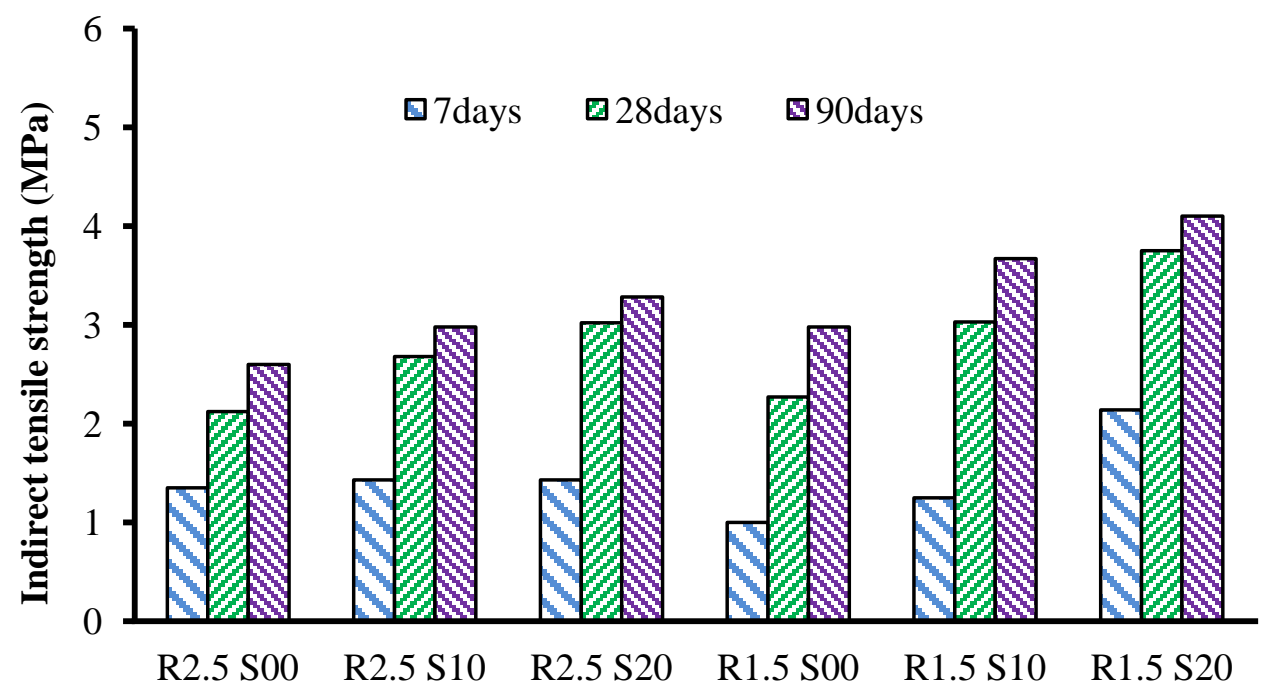

Fig. 7. Splitting tensile strength of geopolymer concrete (Series B, 35\% activator + water) 
Figure 8

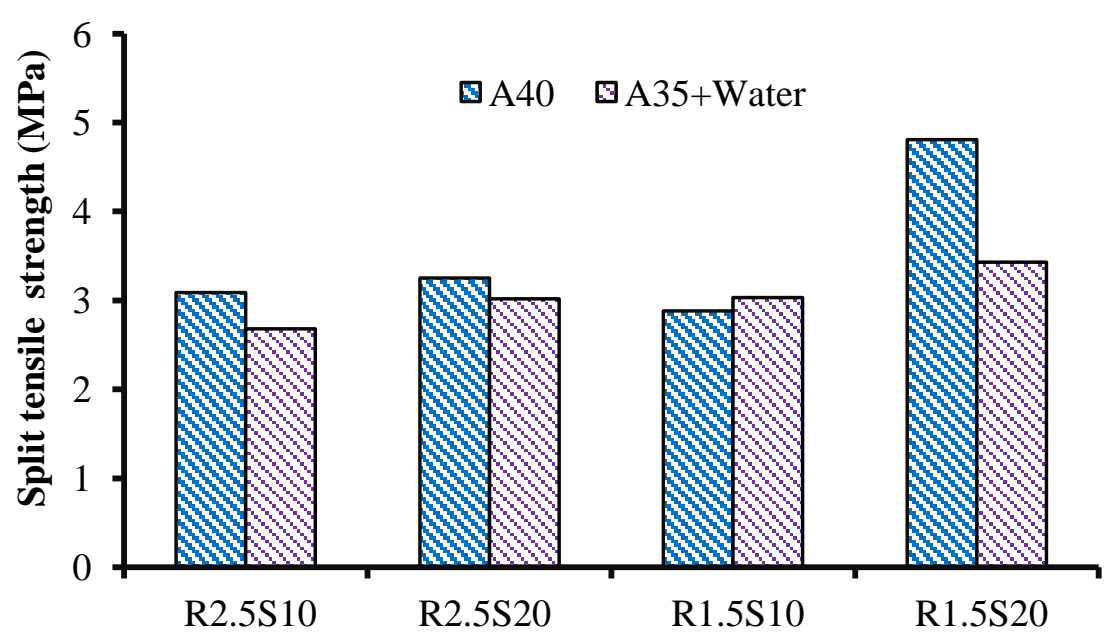

Fig. 8. Change in tensile strength for added water in geopolymer concrete mixtures. 


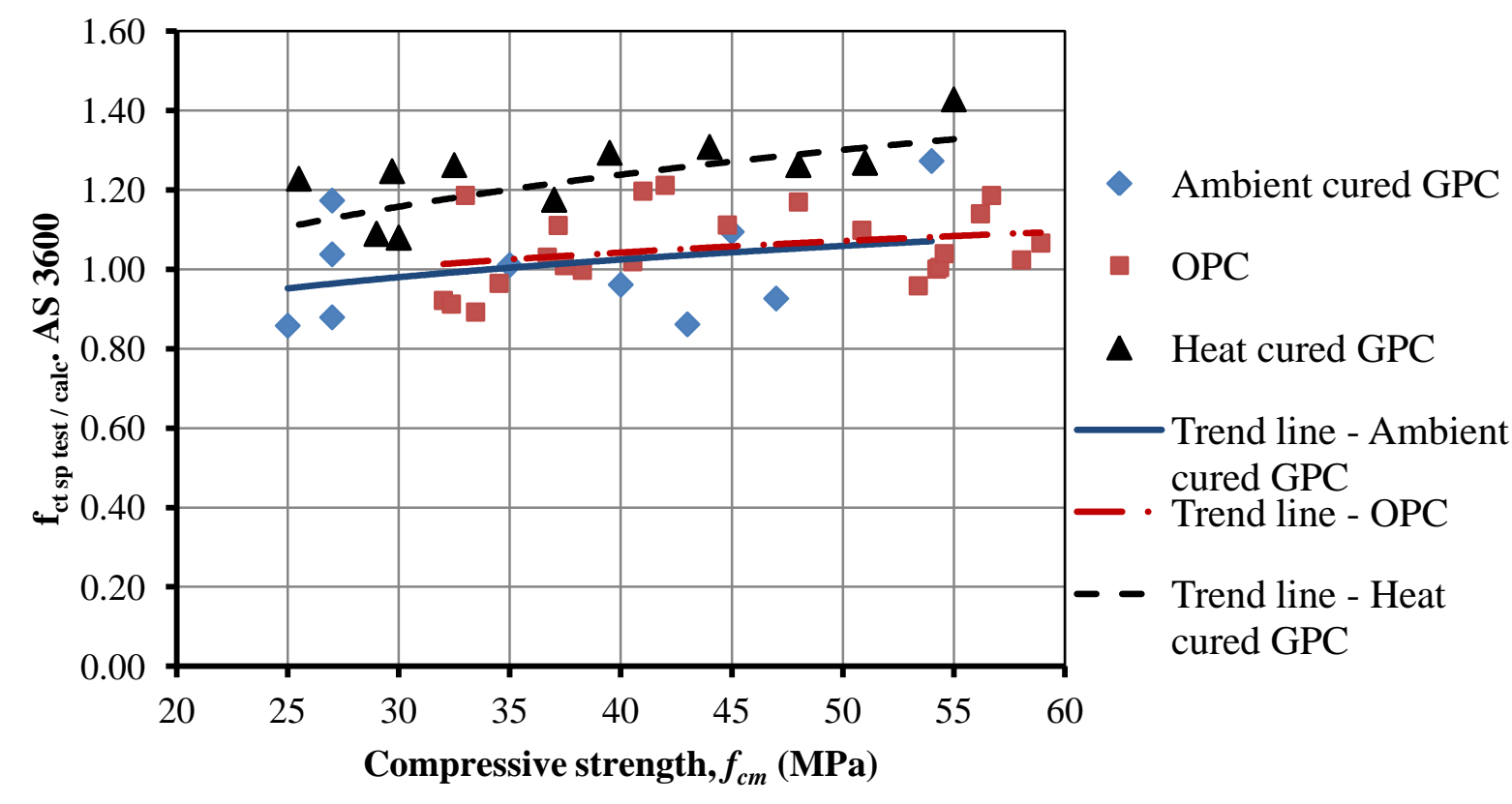

Fig. 9. Ratio of experimental to calculated split tensile strengths of geopolymer concrete by AS3600 


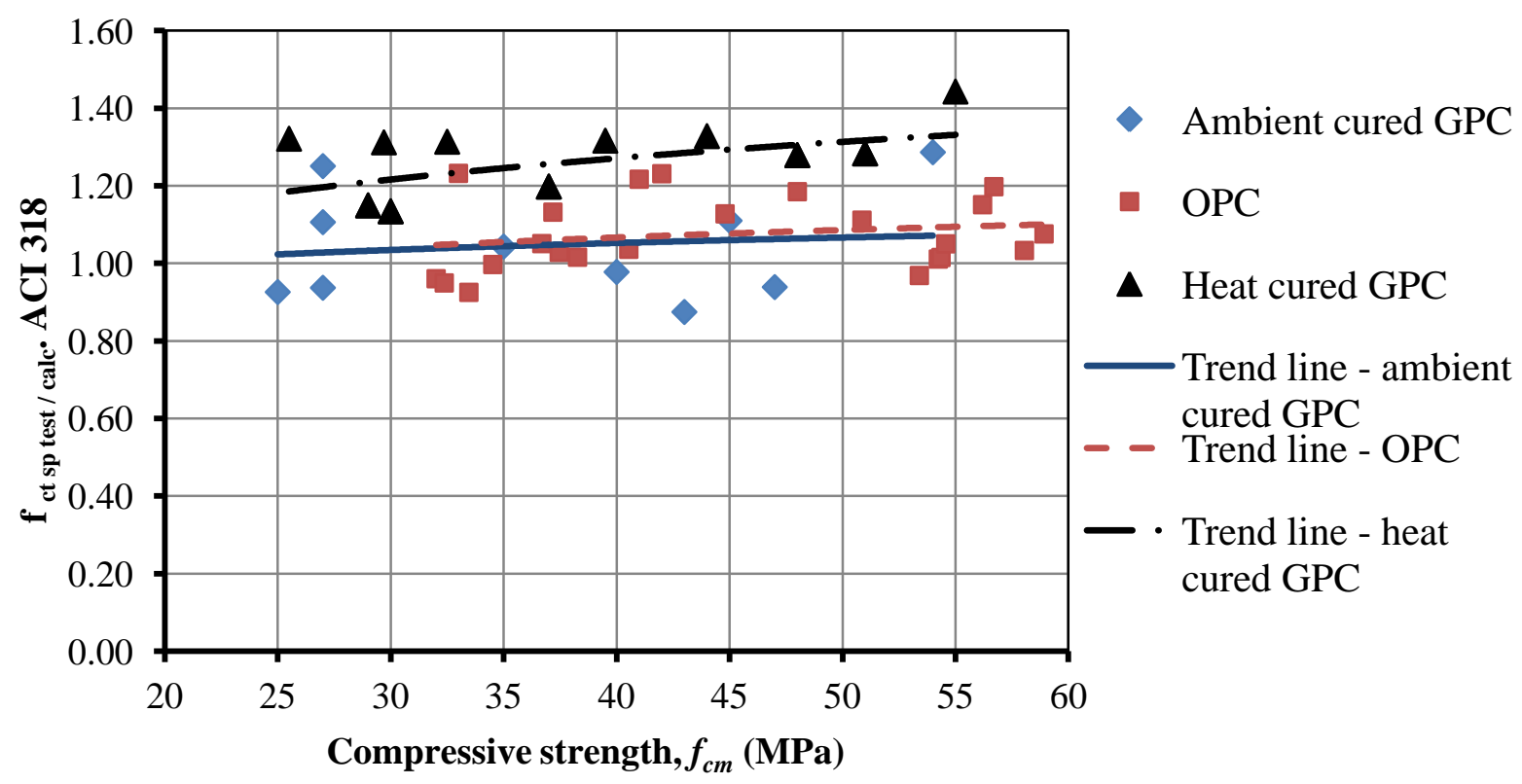

Fig. 10. Ratio of experimental to calculated split tensile strengths of geopolymer concrete by ACI 318 